\title{
Historical review of developing body weight indices: meaning and purpose
}

\begin{abstract}
Rationale: The last century was blossoming with the development of multiple indices to measure body weight. Many researchers aimed to explore the association of extra body weight with various diseases using different approaches of body weight measures. However, there is no summary of developed body mass indices highlighting their strengths and/or weaknesses.
\end{abstract}

Objective: This paper reviews and compares the existing body weight indexes that were developed particularly to define overweight and obesity in relation to adverse health outcomes.

Methods: A systematic literature review was performed to chronologically summarize the development of body weight measures from the first index developed by Quetelet (BMI) in 1832 to Body Adiposity Index (BAI) in 2011.

Conclusion: The paper provides summary of the development and validation of existing body weight indexes. Knowledge of the historical approaches to the measurements of obesity will help researchers to utilize the appropriate body weight assessments to address their objectives. Latin Proverb: "A good beginning ensures a good ending".

Keywords: body weight index, overweight, obesity, epidemic, chronic, body weight
Volume 6 Issue 6 - 2017

\section{Marina Komaroff}

Department of Epidemiology and Biostatistics, SUNY

Downstate Medical Center, USA

Correspondence: Marina Komaroff, Department of Epidemiology and Biostatistics, SUNY Downstate Medical Center, Brooklyn, NY, I I 203, USA, Email Genmar2k@gmail.com

Received: May 08, 2017 | Published: June 09, 2017
Abbreviations: FFM, fat-free-mass; BFM, body fat mass; PBF, percent body fat; SAD, sagittal abdominal diameter; BMI, body mass index

\section{Introduction}

In the beginning of the $20^{\text {th }}$ century the association of obesity and increased mortality became documented by insurance companies. After the World War II, the interest shifted to the association between body weight and morbidity with a question how to classify the excess of body weight that can adversely affect health. This paper reviews the process of development and validation of different body weight indexes. The major milestones of this process are presented in Table 1.

Table I Development of indexes to measure body weight

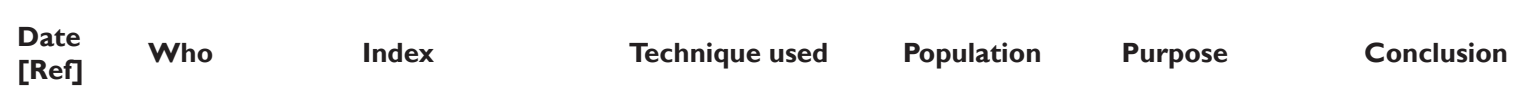

Adolphe
Quetelet

\section{Quatelet} Index=weight/ height ${ }^{2} \mathrm{~W} / \mathrm{H}^{2}$

\begin{abstract}
Anthropometric methods - Direct measure
\end{abstract}

Belgium men and women Define a "Normal
man"
Quetelet suggested first anthropological Index based on observation that weight increases proportionally to height squared.
$1897^{2} \quad$ Livi

$1962^{5}$
W. Z. Billewicz, W. F. F. Kemsley, and A.M. Thomson

\section{$\mathrm{W} / \mathrm{H}$}

$\mathrm{W} / \mathrm{H}^{2}$ $H / W^{1 / 3}(P I)$
Anthropometric

methods -

Direct measure

\section{English}

Anthropometric methods - Direct measure
UK

Obesity

Proposed to measure adiposity or obesity

I. All three indexes highly correlate with adiposity

2. $W / H^{2}$ is less biased (each index selects different proportions of individuals according to their height) 
Table Continued....

\begin{tabular}{|c|c|c|c|c|c|c|}
\hline $\begin{array}{l}\text { Date } \\
\text { [Ref] }\end{array}$ & Who & Index & Technique used & Population & Purpose & Conclusion \\
\hline $1967^{6}$ & $\begin{array}{l}\text { T. Khosla and } \\
\text { C. R. Lowe }\end{array}$ & $\begin{array}{l}\mathrm{I}_{1}=\mathrm{W} / \mathrm{H} \\
\mathrm{I}_{2}=\mathrm{W} / \mathrm{H}^{2} \\
\mathrm{H} / \mathrm{W}^{1 / 3}(\mathrm{PI})\end{array}$ & $\begin{array}{l}\text { Anthropometric } \\
\text { methods - } \\
\text { Direct measure }\end{array}$ & $\begin{array}{l}\text { UK,Birmingham } \\
\text { study of the } \\
\text { distribution } \\
\text { of arterial } \\
\text { pressure in } \\
\text { an industrial } \\
\text { population } \\
\mathrm{N}=5000 \text { men } \\
\text { employed }\end{array}$ & $\begin{array}{l}\text { Compare } 3 \\
\text { indexes to } \\
\text { measure obesity } \\
\text { by } 2 \text { criteria: I) } \\
\text { Correlate with } \\
\text { weight }\left(r_{1}\right) 2 \text { ) } \\
\text { Independent of } \\
\text { height }\left(r_{2}\right)\end{array}$ & $\begin{array}{l}\mathrm{I}_{1}: r_{1}=0.97 r_{2}=.3 \mathrm{I}_{2}: r_{1}=0.85 r_{2} \sim \\
0 \mathrm{I}_{3}: r_{1}=0.6 r_{2}=-0.3 \mathrm{I}_{2} \text { is the most } \\
\text { appropriate for epidemiological } \\
\text { studies ( at least for British pop.) }\end{array}$ \\
\hline $1970^{3}$ & $\begin{array}{l}\text { Charles du V. } \\
\text { Florey }\end{array}$ & $\begin{array}{l}\mathrm{I}_{1}=\mathrm{W} / \mathrm{H} \\
\mathrm{I}_{2}=\mathrm{W} / \mathrm{H}^{2} \\
\mathrm{I}_{3}=\mathrm{W} / \mathrm{H}^{3}= \\
\text { (Rohrer Index-as } \\
\text { variation of } \mathrm{H} / \\
\mathrm{W}^{1 / 3}(\mathrm{Pl}) \text { ) Triceps } \\
\text { skinfold \& } \\
\text { Intrascapullar } \\
\text { skinfold (as best } \\
\text { adiposity } \\
\text { measurements) }\end{array}$ & $\begin{array}{l}\text { Anthropometric } \\
\text { methods - Direct } \\
\text { measure }\end{array}$ & $\begin{array}{l}\text { US, Framingham } \\
\text { Study, } \\
\text { Massachusetts } \\
\mathrm{N}=5 \text { I } 27 \text { free } \\
\text { from coronary } \\
\text { disease at first } \\
\text { exam } \mathrm{N}=454 \text { I } \\
\text { persons were } \\
\text { reexamined } \\
\text { during Exam IV }\end{array}$ & $\begin{array}{l}\text { Compare } 3 \\
\text { indexes to } \\
\text { measure obesity } \\
\text { and adiposity }\end{array}$ & $\begin{array}{l}\text { I. Western male population was } \\
\text { Quetelet Index }\left(\mathrm{W} / \mathrm{H}^{2}\right) \text {, probable } \\
\text { in Western female population } \\
\text { was } \mathrm{W} / \mathrm{H} \text {; and the least likely for } \\
\text { both sexes was Ponderal Index. } \\
\text { 2. All indexes are poor } \\
\text { measurements of } \\
\text { Adiposity }\end{array}$ \\
\hline $1972^{7}$ & $\begin{array}{l}\text { A. Keys, F. } \\
\text { Fidanza, M. J. } \\
\text { Karvonen N. } \\
\text { Kimura And H. } \\
\text { L. Taylor }\end{array}$ & $\begin{array}{l}\text { W/H } \\
\text { W/H² } \\
\mathrm{PI} \\
\% W \text { (\%from weight } \\
\text { standard at given } \\
\text { height) }\end{array}$ & $\begin{array}{l}\text { Anthropometric } \\
\text { methods - Direct } \\
\text { measure }\end{array}$ & $\begin{array}{l}\text { Several } \\
\text { countries in } \\
\text { Europe, Japan, } \\
\text { men } \\
\text { in South Africa, } \\
\text { white } \\
\text { men in the } \\
\text { United } \\
\text { States } \\
7424 \text { 'healthy' } \\
\text { men in } \\
12 \text { cohorts in } \\
\text { five } \\
\text { countries. } \\
\text { Body density in } \\
\mathrm{N}=180 \\
\text { young men } \\
\text { and in } \\
248 \text { men aged } \\
49-59 .\end{array}$ & $\begin{array}{l}\text { Criteria of } \\
\text { correlation } \\
\text { with height } \\
\text { (lowest is } \\
\text { best) and to } \\
\text { measures } \\
\text { of } \\
\text { body fatness } \\
\text { (highest } \\
\text { is best) }\end{array}$ & $\begin{array}{l}\mathrm{PI} \text { is the poorest } \\
\mathrm{W} / \mathrm{H}^{2}-\text { is the best } \\
\text { Body Mass Index (BMI) } \\
\text { which is } \mathrm{W} / \mathrm{H}^{2} \text { is } \\
\text { preferable measure to } \\
\text { "all populations in all } \\
\text { times" }\end{array}$ \\
\hline $1990^{18}$ & $\begin{array}{l}\text { Theodore B } \\
\text { Vanltaiie, Mei- } \\
\text { Uih Yang, } \\
\text { Steven B } \\
\text { Heymsfield, } \\
\text { Robert C Funk, } \\
\text { and Richard A } \\
\text { Boileau }\end{array}$ & $\begin{array}{l}\mathrm{FFMI}=\mathrm{FFM}(\mathrm{kg}) / \\
\mathrm{H}(\mathrm{m})^{2}, \\
\mathrm{BFMI}=\mathrm{BFM}(\mathrm{kg}) / \\
\mathrm{H}(\mathrm{m})^{2}\end{array}$ & $\begin{array}{l}\text { TOBEC by } \\
\text { electromagnetic } \\
\text { scanning } \\
\text { instrument (EM- } \\
\text { SCAN, model HA- } \\
\text { 2, Springfield, IL) - } \\
\text { FFM } \\
\text { Hydrodensitometry } \\
\text { in all } 32 \text { subjects } \\
\text { for Body } \\
\text { Composition }\end{array}$ & $\begin{array}{l}\text { I } 24 \text { healthy and } \\
32 \text { Non-obese } \\
\text { young } \\
\text { men (from the } \\
\text { Minnesota } \\
\text { Study) } \\
\text { before, during, } \\
\text { and } \\
\text { after } \\
\text { experimental } \\
\text { semi-starvation. }\end{array}$ & $\begin{array}{l}\text { To demonstrate } \\
\text { the clinical value } \\
\text { of } \\
\text { the FFMI and the } \\
\text { BFMI } \\
\text { (can be helpful } \\
\text { in the } \\
\text { nutritional } \\
\text { assessment } \\
\text { of patients). }\end{array}$ & $\begin{array}{l}\text { Defined FFMI and BFMI that may } \\
\text { be used in nutritional assessment } \\
\text { (cutoff points should be chosen in } \\
\text { more representative population }\end{array}$ \\
\hline$\left.199\right|^{15}$ & $\begin{array}{l}\text { Paul } \\
\text { Deurenberg, } \\
\text { Jan A. } \\
\text { Weststrate, } \\
\text { and Jaap C. } \\
\text { Seidell }\end{array}$ & $\begin{array}{l}\text { \%Body Fat \%BF } \\
\text { Formula for } \\
\text { children and } \\
\text { adult using BMI }\end{array}$ & $\begin{array}{l}\text { \%BF - } \\
\text { densitometry } \\
\text { (underwater } \\
\text { weight + Siri's } \\
\text { formula) BMI- } \\
\text { anthropometry }\end{array}$ & $\begin{array}{l}\text { In } 1229 \\
\text { subjects, } 52 \text { I } \\
\text { males and } 708 \\
\text { females, with a } \\
\text { wide } \\
\text { range in body } \\
\text { mass } \\
\text { index (BMI; } \\
\text { I3.9-40.9kg/ } \\
\text { m2), and } \\
\text { an age range of } \\
7-83 y e a r s\end{array}$ & $\begin{array}{l}\text { Compare } \mathrm{BMI} \text { and } \\
\% \mathrm{BF}\end{array}$ & $\begin{array}{l}\text { Child \%BF }=(\mathrm{I} .5 \mathrm{I} \times \mathrm{BMI}) \\
-(0.70 \times \mathrm{Age})-(3.6 \times \\
\text { Sex })+\mathrm{I} .4 \\
\text { Adult } \% \mathrm{BF}=(\mathrm{I} .20 \times \mathrm{BMI}) \\
+(0.23 \times \mathrm{Age})-(\mathrm{I} 0.8 \times \\
\text { Sex })-54\end{array}$ \\
\hline
\end{tabular}




\begin{tabular}{|c|c|c|c|c|c|c|}
\hline $\begin{array}{l}\text { Date } \\
\text { [Ref] }\end{array}$ & Who & Index & Technique used & Population & Purpose & Conclusion \\
\hline $2002^{19}$ & $\begin{array}{l}\text { Y Schutz, UUG } \\
\text { Kyle and C } \\
\text { Pichard }\end{array}$ & $\begin{array}{l}\text { FFMI (fat-free } \\
\text { mass=height } \\
\text { squared) } \\
\text { and } \\
\text { FMI (fat } \\
\text { mass=height } \\
\text { squared). }\end{array}$ & $\begin{array}{l}\text { Bioelectrical } \\
\text { impedance } \\
\text { analysis }(50 \mathrm{kHz}) \\
\text { was measured } \\
\text { (using tetrapolar } \\
\text { electrodes } \\
\text { and cross- validated } \\
\text { formulae by dual- } \\
\text { energy X- ray } \\
\text { absorptiometry }\end{array}$ & $\begin{array}{l}5635 \text { apparently } \\
\text { healthy adults } \\
\text { from a } \\
\text { mixed non- } \\
\text { randomly } \\
\text { selected } \\
\text { Caucasian } \\
\text { population in } \\
\text { Switzerland } \\
\text { ( } 2986 \text { men and } \\
2649 \text { women), } \\
\text { at age from } 24 \\
\text { to } 98 y \text {. }\end{array}$ & $\begin{array}{l}\text { To determine } \\
\text { reference values } \\
\text { for } \\
\text { fat-free mass } \\
\text { index } \\
\text { (FFMI) and fat } \\
\text { mass index (FMI) } \\
\text { as a function of } \\
\text { age and } \\
\text { gender and to } \\
\text { develop percentile } \\
\text { distribution for } \\
\text { them. }\end{array}$ & $\begin{array}{l}\text { Reference intervals for } \\
\text { FFMI and FMI } \\
\text { (BMI international criteria was used } \\
\text { as cutoff points for calculation of } \\
\text { corresponding FFMI and FMI values) }\end{array}$ \\
\hline $2006^{22}$ & $\begin{array}{l}\text { Iribarren, } \\
\text { Carlos; } \\
\text { Darbinian, } \\
\text { Jeanne A.; } \\
\text { Lo, Joan C.; } \\
\text { Fireman, Bruce } \\
\text { H.; Go, Alan S }\end{array}$ & $\begin{array}{l}\text { Association } \\
\text { between } \\
\text { visceral obesity } \\
\text { measured by SAD } \\
\text { and } \\
\text { coronary heart } \\
\text { disease (CHD) }\end{array}$ & $\begin{array}{l}\text { Anthropometric } \\
\text { measure: Standing } \\
\text { SAD }(\mathrm{cm})\end{array}$ & $\begin{array}{l}\text { I0I,765 adult } \\
\text { members } \\
\text { of Kaiser } \\
\text { Permanente of } \\
\text { Northern } \\
\text { California }\end{array}$ & $\begin{array}{l}\text { Association } \\
\text { between } \\
\text { visceral obesity } \\
\text { measured by SAD } \\
\text { and coronary } \\
\text { heart disease } \\
(\mathrm{CHD})\end{array}$ & $\begin{array}{l}\text { SAD was a strong } \\
\text { predictor of CHD independently } \\
\text { of BMI; } \\
\text { the joint consideration of BMI/SAD } \\
\text { categories as better assessment risk } \\
\text { of CHD compared with use of BMI } \\
\text { alone }\end{array}$ \\
\hline
\end{tabular}

Whitmer, R.A.; Gustafson, D. R.; Barrett-

$2008^{26}$ Connor, E.;

Haan, M. N.;

Gunderson, E.

P.; Yaffe, $K$
Association

between visceral obesity measured by SAD and dementia

$\begin{array}{ll}\text { Anthropometric } & \begin{array}{l}\text { A longitudinal } \\ \text { study } \\ \text { measure: Standing }\end{array} \\ \text { included 6,583 } \\ \text { distance between } & \text { members of } \\ \text { Kaiser } \\ \text { the back surface } & \text { Permanente of } \\ \text { and the top of the } & \text { Northern } \\ \text { abdomen at the } & \text { California; } \\ \text { level of the iliac } & \text { (SAD) } \\ \text { crest after gentle } & \text { measured in } \\ \text { expiration with the } & \text { I964 to I973, } \\ \text { patient in a } & \text { I,049 } \\ \text { standing position } & \text { participants } \\ \text { using an } & \text { (I5.9\%) were } \\ \text { anthropometer; } & \text { diagnosed with } \\ \text { High SAD } \geq 25 \mathrm{~cm} & \text { dementia } \\ \text { Low SAD }<25 \mathrm{~cm} & 36 y e a r s\end{array}$

Abel RomeroCorral,Virend K. Somers, Justo SierraJohnson,,

Randal J.

Thomas, Kent

\section{Collazo-}

Clavell, Thomas

G.Allison, Josef

Korinek,

John A. Batsis,

and Francisco

Lopez-

Jimenez

Accuracy of

$\mathrm{BMI} \geq 30 \mathrm{~kg} / \mathrm{m}^{2}$ to

detect excess in

body adiposity

compared to Body

Fat\%

BMI-defined obesity

$\left(\geq 30 \mathrm{~kg} / \mathrm{m}^{2}\right)$ was

present in $21 \%$ of

men and $31 \%$ of

women, while

BF \%-defined

obesity was present

in $50 \%$ and $62 \%$,

respectively
Using the

World Health

|3,60| subjects (age

20-79.9years;

Bioelectrical

impedance analysis

was used

to estimate body fat percent (BF \%).

$48 \%$ men) from

the

Third National

Health and

Nutrition

Examination

Survey.

NHANES III

obesity (based
Association

between

visceral obesity

measured by SAD

and dimensia
Visceral obesity

increases risk of

dementia independent of

diabetes and

cardiovascular co-

morbidities among mid-

aged population

\section{Organization}

reference

standard for

on BMI cut offs):

Obesity of BF \% >

$25 \%$ in men and >

$35 \%$ in women.

Correlation

between BMI and

both, BF \% and

lean mass by sex

and age groups.
Diagnostic accuracy of

$\mathrm{BMI}$ to diagnose obesity is limited (for individuals

in the intermediate $\mathrm{BMI}$ ranges).

A BMI cut-off of $\geq 30 \mathrm{~kg} / \mathrm{m}^{2}$ has a

good

specificity but misses more than half of people with excess fat. May explain differences in shapes ( $U$ or J) of association between BMI and Health Outcomes. 
Table Continued...

\begin{tabular}{|c|c|c|c|c|c|c|}
\hline $\begin{array}{l}\text { Date } \\
\text { [Ref] }\end{array}$ & Who & Index & Technique used & Population & Purpose & Conclusion \\
\hline $2008^{37}$ & $\begin{array}{l}\text { The WHO } \\
\text { Expert } \\
\text { Consultation }\end{array}$ & $\begin{array}{l}\text { WC =waist circumf. } \\
\text { HC=hip circumf. } \\
\text { WHR = the waist } \\
\text { circumference } \\
\text { divided by } \\
\text { the hip } \\
\text { circumference } \\
\text { Or } \\
\text { WHR=WC/HC }\end{array}$ & $\begin{array}{l}\text { Waist } \\
\text { circumference } \\
\text { (WC)- measured } \\
\text { at the midpoint } \\
\text { between the lower } \\
\text { margin of the least } \\
\text { palpable rib and } \\
\text { the top of the iliac } \\
\text { crest, using a } \\
\text { stretch-resistant } \\
\text { tape that provides } \\
\text { a constant I00 g } \\
\text { tension. } \\
\text { Hip circumference } \\
\text { (HC) should be } \\
\text { measured around } \\
\text { the widest portion } \\
\text { of the buttocks, } \\
\text { with the tape } \\
\text { parallel to floor. }\end{array}$ & $\begin{array}{l}\text { US and global } \\
\text { Summarizes } \\
\text { issues to } \\
\text { define cutoffs } \\
\text { globally }\end{array}$ & $\begin{array}{l}\text { Report of a Waist } \\
\text { Circumference } \\
\text { and } \\
\text { Waist-Hip Ratio }\end{array}$ & $\begin{array}{l}\text { Defines and summarizes } \\
\text { the techniques of } \\
\text { measurements WC, HC, } \\
\text { and WHR }\end{array}$ \\
\hline $2009^{20}$ & $\begin{array}{l}\text { Thomas L. } \\
\text { Kelly, Kevin E. } \\
\text { Wilson, Steven } \\
\text { B. Heymsfield }\end{array}$ & $\begin{array}{l}\text { \%BF, fat mass/ } \\
\text { height }^{2} \text {, } \\
\text { lean mass/height }{ }^{2} \text {, } \\
\text { appendicular lean } \\
\text { mass/height }{ }^{2} \text { \% fat } \\
\text { trunk/\%fat legs ratio, } \\
\text { trunk/limb fat mass } \\
\text { ratio of fat, bone } \\
\text { mineral } \\
\text { content (BMC) and } \\
\text { bone } \\
\text { mineral density } \\
\text { (BMD) }\end{array}$ & $\begin{array}{l}\text { Dual energy x-ray } \\
\text { absorptiometry } \\
\text { (DXA) }\end{array}$ & $\begin{array}{l}\text { NHANES III } \\
\text { I } 5 \text { counties } \\
\text { across the } \\
\text { United States } \\
\text { from } 1999 \\
\text { through } \\
2004\end{array}$ & $\begin{array}{l}\text { Developed } \\
\text { Classification } \\
\text { thresholds for } \\
\text { Fat Mass Index } \\
\text { (FMI; fat } \\
\text { mass/height }{ }^{2} \text { ). } \\
\text { ( by using BMI } \\
\text { classification } \\
\text { thresholds and } \\
\text { prevalence in } \\
\text { young } \\
\text { adults) }\end{array}$ & $\begin{array}{l}\text { These reference values } \\
\text { should be helpful in } \\
\text { establishing entry criteria into } \\
\text { clinical trials, and for } \\
\text { other medical, research, } \\
\text { and epidemiological uses. }\end{array}$ \\
\hline $2010^{21}$ & $\begin{array}{l}\text { Gerson Peltz, } \\
\text { Maria Teresa } \\
\text { Aguirre, } \\
\text { Maureen } \\
\text { Sanderson And } \\
\text { Mary K. } \\
\text { Fadden }\end{array}$ & $\begin{array}{l}\text { Compare BMI, PBF, } \\
\text { and } \\
\text { FMI; } \\
\text { and to investigate } \\
\text { the } \\
\text { accuracy of FMI as a } \\
\text { convenient tool for } \\
\text { assessing obesity }\end{array}$ & $\begin{array}{l}\text { Anthropometric } \\
\text { measurements } \\
\text { and bioelectrical } \\
\text { impedance analyses } \\
\text { (BIA) }\end{array}$ & $\begin{array}{l}538 \text { Mexican } \\
\text { American } \\
\text { college students } \\
\text { ( } 373 \\
\text { women and I } 65 \\
\text { men) } \\
\text { from the } \\
\text { University } \\
\text { of Texas at } \\
\text { Brownsville } \\
\text { and Texas } \\
\text { Southmost } \\
\text { College (UTB/ } \\
\text { TSC); } \\
\text { recruited from } \\
\text { September } \\
2004 \text { through } \\
\text { December } \\
2005 \text {. }\end{array}$ & $\begin{array}{l}\text { Correlation } \\
\text { between } \\
\text { FMI and PBF in } \\
\text { men } \\
(r=0.975 ; \\
P<0.000 I) \\
\text { and women } \\
(r=0.992 ; \\
P<0.0001) \text { while } \\
\text { misclassification } \\
\text { of } \\
\text { obesity between } \\
\text { FMI } \\
\text { and PBF } \\
\text { categories } \\
\text { was observed in } \\
\text { only } \\
5.4 \% \text { of men and } \\
7.8 \% \\
\text { of women. }\end{array}$ & $\begin{array}{l}\text { Limitation of BMI: High } \\
\text { correlation b/w BMI and } \\
\text { PBF in men }(r=0.877 ; \mathrm{P}< \\
0.000 \mathrm{I}) \text { and women }(\mathrm{r}=0.966 ; \\
\mathrm{P}<0.000 \mathrm{I}) \text {; } \\
\text { however, } 67.2 \% \text { of the } \\
\text { men and } 84.2 \% \text { of women } \\
\text { were miss-classified as } \\
\text { normal weight and } \\
\text { overweight by BMI while } \\
\text { diagnosed as obese by } \\
\text { PBF. } \\
\text { FMI accurately } \\
\text { assessed obesity in this } \\
\text { study of Mexican } \\
\text { Americans }\end{array}$ \\
\hline${ }_{31}^{2010^{27-}}$ & $\begin{array}{l}\text { The Body } \\
\text { Benchmark } \\
\text { Study; } \\
\text { US and EU }\end{array}$ & $\begin{array}{l}\text { Development and } \\
\text { Validation of } \\
\text { Body Volume Index } \\
\text { BVI }\end{array}$ & $\begin{array}{l}\text { 3-dimensional } \\
\text { photonic scanner } \\
\text { 3DPS }\end{array}$ & US and Europe & $\begin{array}{l}\text { Development of } \\
\text { new } \\
\text { Anthropometric } \\
\text { index: } \\
\text { BVI is accurate, } \\
\text { easy } \\
\text { to measure, no } \\
\text { variability } \\
\text { between } \\
\text { evaluators. }\end{array}$ & $\begin{array}{l}\text { Definition and Validation } \\
\text { of BVI }\end{array}$ \\
\hline
\end{tabular}


Table Continued....

\begin{tabular}{lllll}
\hline $\begin{array}{l}\text { Date } \\
\text { [Ref }]\end{array}$ & Who Index & Technique used & Population & Purpose
\end{tabular}

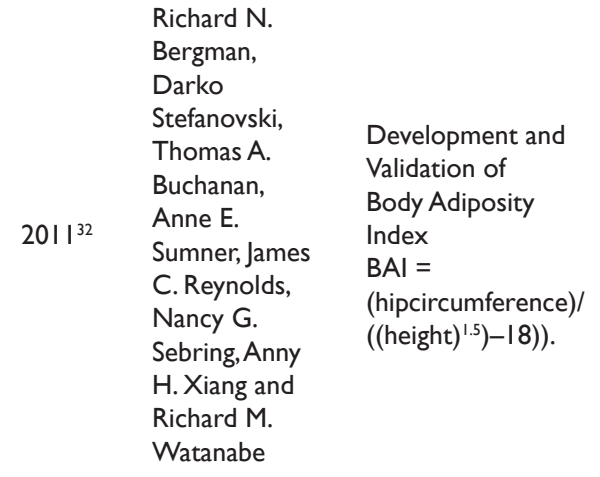

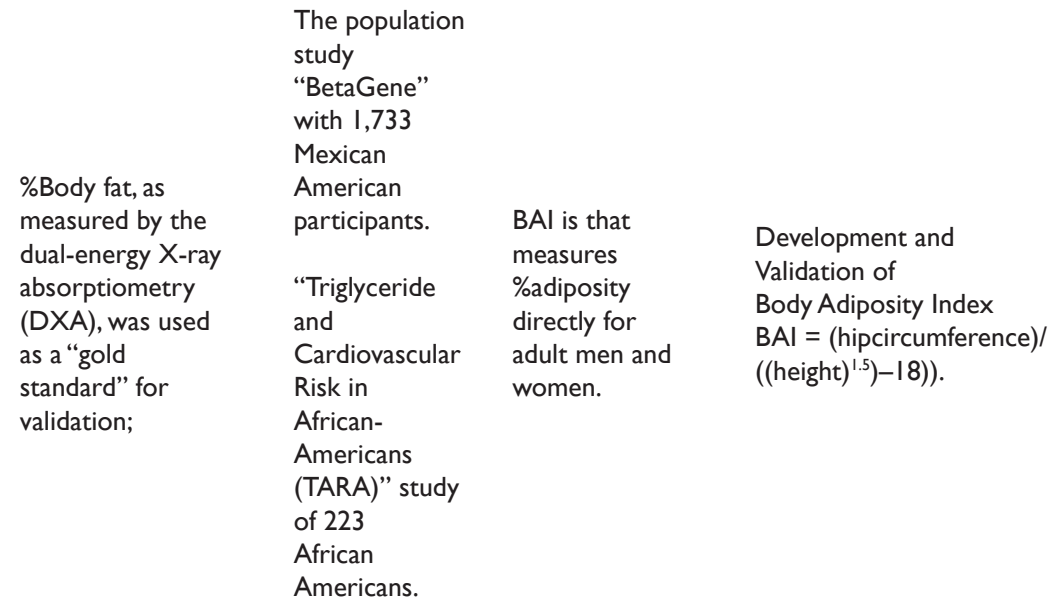

Note:W, weight; $\mathrm{H}$, height

\section{Weight-to-height indexes}

In 1832, the Quetelet index (later was renamed into the Body Mass Index or BMI) was defined as body weight divided by height squared: BMI $=$ Weight $/$ Height $^{2},{ }^{1}$ and in 1897 , the Ponderal Index was introduced by Rudolfo Livi ${ }^{2}$ as height divided by the cube root of weight PI=Height/(Weight $)^{1 / 3} \cdot{ }^{2,3}$ In 1921, Roher proposed the Corpulence Index as a measure of leanness of a person where body weight was normalized by the third power of body height rather than the second power $\mathrm{RI}=$ Weight/Height. ${ }^{3,4}$ By the mid of $20^{\text {th }}$ century, the most popular indexes became: $\mathrm{W} / \mathrm{H}, \mathrm{W} / \mathrm{H}^{2}$, and $\mathrm{H} / \mathrm{W}^{1 / 3}$ (Table 1). Quetelet index was less "biased" in terms of independence from height (coefficients of correlation $r \leq 0.16$ ) and from this point of view Quetelet index was considered the best. ${ }^{5}$

Khosla and Lowe ${ }^{6}$ also had an objective to compare the three indexes: $\mathrm{I}_{1}=\mathrm{W} / \mathrm{H}, \mathrm{I}_{2}=\mathrm{W} / \mathrm{H}^{2}$, and $\mathrm{I}_{3}=\mathrm{W} / \mathrm{H}^{3}$ using the data from Birmingham survey and two criteria for the best index:

i. The highest correlation with the weight; and

ii. Independence from the height. ${ }^{6}$

The results demonstrated that $I_{2}$ was highly correlated with weight $\left(r_{1}=0.85\right)$ and consistently independent from height. ${ }^{6}$ The authors concluded that Quetelet index $\mathrm{I}_{2}=\mathrm{W} / \mathrm{H}^{2}$ was the best choice for epidemiological purposes. ${ }^{6}$ Both studies by Charles du V Florey focused on the meaning of indexes as the measure of obesity and how to choose the most appropriate index for the particular population. ${ }^{3}$ The author used Framingham Heart Study (FHS) data that included subjects free of coronary heart disease at the first examination $(\mathrm{N}=5127)$; then 4541 of them were reexamined during Exam IV (6-years follow-up, and 88.6 percent of the original respondents). ${ }^{3}$ Height, weight, triceps, and skinfold thickness data were collected with a goal to compare the properties of three weight to height indexes: $\mathrm{W} / \mathrm{H}, \mathrm{W} / \mathrm{H}^{2}$, and $\mathrm{PI}=\mathrm{H} /(\mathrm{W})^{1 / 3}{ }^{3}$. The authors suggested that regression model should be developed for the particular population and the best of the three proposed ratios will depend on the value of the intercept and the coefficient of the regression of weight on height. ${ }^{3}$ For example, index $\mathrm{W} / \mathrm{H}$ is the best when the coefficient $b=2$ because of most independence from height; and $\mathrm{W} / \mathrm{H}^{2}$ is least dependent on height when $\mathrm{b}=5$. Based on this approach, the authors concluded that the "most likely" best ratio in Western male population was Quetelet Index $\left(\mathrm{W} / \mathrm{H}^{2}\right)$, "probable" in Western female population was $\mathrm{W} / \mathrm{H}$; and the "least likely" for both sexes was Ponderal Index. ${ }^{3}$ All three indexes were poor measures of adiposity because of low correlation with triceps $(<0.5)$ and infra-scapular skinfold $(<0.7)$ for both males and females. ${ }^{3}$

Keys et al., ${ }^{7}$ decided to repeat analyses on "calibrated" data, in the other words to compare the various indices of relative weight as applied to data on weight, height and body fatness of men in several countries in Europe, Japan, South Africa, as well as white men in the United States. ${ }^{7}$ The criteria for the best index was independence from height, and the highest correlation with the body fatness. ${ }^{7}$ The Quetelet Index was named as Body Mass Index (BMI) first time and it was pronounced preferable over other indices of relative weight $\left(\% \mathrm{~W}, \mathrm{~W} / \mathrm{H}, \mathrm{W} / \mathrm{H}^{2}, \mathrm{~W} / \mathrm{H}^{3}\right.$, and $\left.\mathrm{PI}\right)$ judged by the criteria of correlation with height (lowest is best) and body fatness (highest is best) as well as "on the simplicity of the calculation and, in contrast to percentage of average weight, the applicability to all populations at all times"?

BMI became the most common index to measure weight status in adults. BMI is a continuous variable and the threshold for overweight and obesity was not an easy task for many years. Currently, World Health Organization international classification of BMI based on association with mortality is used (Table 2). Nevertheless, BMI has a few serious limitations. Assessment of BMI in epidemiological studies assumes an average person with the average physical activity (presumably: not athletes, not elderly) and with an average body composition. ${ }^{7}$ BMI is not a good proxy for fat distribution and cannot separate lean fat from body fat mass while the difference how the same amount of extra fat is distributed in the bodies can substantially modify the risk associated with obesity., ${ }^{4-14}$ Those limitations promoted search for the other measurements of obesity. 
Table 2 Fat mass index $\left(\mathrm{kg} / \mathrm{m}^{2}\right)$ classification ranges

\begin{tabular}{|c|c|c|c|c|c|c|c|c|}
\hline \multirow{2}{*}{$\begin{array}{l}\text { FMI } \\
\text { Class }\end{array}$} & \multicolumn{3}{|c|}{ Fat deficit } & \multirow{2}{*}{ Normal } & \multirow{2}{*}{ Excess fat } & \multicolumn{3}{|c|}{ Obese class } \\
\hline & Severe & Moderate & Mild & & & I & II & III \\
\hline Male & $<2$ & 2 to $<2.3$ & 2.3 to $<3$ & 3-Jun & $>6$ to 9 & $>9$ to 12 & $>12$ to 15 & $>15$ \\
\hline Female & $<3.5$ & 3.5 to $<4$ & 4 to $<5$ & 5-Sep & $>9$ to 13 & $>13$ to 17 & $>17$ to 21 & $>21$ \\
\hline
\end{tabular}

\section{Percent body fat (PBF or \%BF)}

Percent body fat $(\% \mathrm{BF})$ is the total mass of fat (or fat accumulated in adipose tissue) divided by total weight: \%BF=Body Fat Mass/ Body Weight. Percent body fat can be calculated from skinfolds or other anthropometric methods such as bioelectrical Impedance. The relationship between body fat percentage $(\% \mathrm{BF})$ and $\mathrm{BMI}$ adjusted for age and sex was investigated by Deurenberg et al., ${ }^{15 \% \mathrm{BF}}$ was calculated from the body density uning Siri's ${ }^{16}$ formula where the body density was measured by underwater weighing (UWW). ${ }^{15}$ The authors estimated that \% $\mathrm{BF}$ could be derived by the following formulas: Child $\% B F=(1.51 \times \mathrm{BMI})-(0.70 \times \mathrm{Age})-(3.6 \mathrm{x} \mathrm{Sex})+1.4$; and Adult $\% B F=(1.20 \mathrm{x} \quad \mathrm{BMI})+(0.23$ x Age $)-(10.8 \mathrm{xSex})-54$ (males $=1$, females $=0$ ). Deurenberg et al., ${ }^{15}$ concluded that the use of prediction formulas is inexpensive method that does not rely on well-trained observers; moreover, the prediction error is comparable with other methods such as skin-fold thickness measurements or bioelectrical impedance. ${ }^{15}$

The accuracy of BMI to detect excess in body adiposity was assessed by comparing the prevalence of BMI-defined obesity $\left(\geq 30 \mathrm{~kg} / \mathrm{m}^{2}\right)$ versus to reference standard for BF\%-defined obesity of $\mathrm{BF} \%>25 \%$ in men and $>35 \%$ in women in 13,601 subjects from the United States' third National Health and Nutrition Examination Survey (NHANES III). ${ }^{17}$ It was estimated that presence of obesity based on BMI-defined obesity $\left(\geq 30 \mathrm{~kg} / \mathrm{m}^{2}\right)$ was $21 \%$ for men and $31 \%$ for women, versus $50 \%$ and $62 \%$, respectively by BF \% -defined obesity ( $>25 \%$ in men and $>35 \%$ in women). ${ }^{17}$ High specificity (95\% in men and $99 \%$ in women) and poor sensitivity (36\% and $49 \%$, respectively) was demonstrated by BMI $\geq 30 \mathrm{~kg} / \mathrm{m}^{2}$ to detect $\%$ BF-defined obesity. ${ }^{17} \mathrm{BMI}$ had a good correlation with $\% \mathrm{BF}$ in men $\left(\mathrm{R}^{2}=0.44\right)$ and women $\left(\mathrm{R}^{2}=0.71\right)$, but in spite of that the accuracy to diagnose obesity by BMI was limited, and using BMI cut-off as $\geq 30 \mathrm{~kg} / \mathrm{m}^{2}$ missed more than half of people with excess fat. ${ }^{17}$

\section{Fat-Free-Mass (FFM) and Body Fat Mass (BFM)}

In 1990, Vanltallie et al. ${ }^{18}$ proposed height-normalized indices like Fat Free Mass Index: FFMI $=$ Fat-Free-Mass $(\mathrm{kg}) / \operatorname{Height}(\mathrm{m})^{2}$, and Body Fat Mass Index: BFMI=Body-Fat-Mass $(\mathrm{kg}) / \operatorname{Height}(\mathrm{m})^{2}$ as a possible alternative to BMI (it can be noticed that mathematically $\left.\operatorname{BMI}\left(\mathrm{kg} / \mathrm{m}^{2}\right)=\mathrm{FFMI}\left(\mathrm{kg} / \mathrm{m}^{2}\right)+\mathrm{BFMI}\left(\mathrm{kg} / \mathrm{m}^{2}\right)\right) .{ }^{18}$ The objective of the Vanltallie et al., ${ }^{18}$ study was to demonstrate the clinical value of FFMI and BFMI in terms of the nutritional assessment, because tall subjects with protein-energy malnutrition (PEM) and short wellnourished individuals may have the same FFM and BFM values. ${ }^{18}$ The authors calculated $\mathrm{FFMI}=\mathrm{FFM}(\mathrm{kg}) / \mathrm{H}(\mathrm{m})^{2}$ and $\mathrm{BFMI}=\mathrm{BFM}(\mathrm{kg}) /$ $\mathrm{H}(\mathrm{m})^{2}$ before, during, and after experimental semi-starvation for subjects from Minnesota Study. ${ }^{18}$ The criteria for PEM was set up as FFMI and BFMI fall below the $5^{\text {th }}$ percentile in reference cohort of 124 healthy men, and 32 non- obese young men. ${ }^{18}$ Based on this criteria, 27 out of 32 Minnesota subjects were diagnosed in PEM after $12 \mathrm{weeks}$ of semi-starvation. ${ }^{18}$ Vanltallie et al., ${ }^{18}$ concluded that FFMI and BFMI may be useful in nutritional assessment. ${ }^{18}$
In 2002, Schultz et al., ${ }^{19}$ conducted a cross-sectional study to determine reference values for fat-free mass index (FFMI) and fat mass index (FMI) in a large Caucasian group of healthy subjects from Switzerland (2986 men and 2649 women, 24-98years of age) as a function of age and gender, with the additional goal to develop percentile distribution for these two indexes. ${ }^{19}$ The authors used the classical BMI cut-off points as of $18.5,20$ and $25 \mathrm{~kg} / \mathrm{m}^{2}$ to determine the corresponding values for FFMIs and FMIs by means of regression analysis of BMI vs. FFMI, then vs. FMI, and demonstrated that the 25 and 75-percentiles for FFMI and FMI distribution corresponded well to the cut-off of BMI's as 20 and $25 \mathrm{~kg} / \mathrm{m}^{2}$ respectively. ${ }^{19}$ It was observed (especially in women): at a BMI of $20 \mathrm{~kg} / \mathrm{m}^{2}$ the corresponding FFMI was $15.1 \mathrm{~kg} / \mathrm{m}^{2}$, and at 25 percentile $=15.0 \mathrm{~kg} /$ $\mathrm{m}^{2}$; similarly, at a BMI of $25 \mathrm{~kg} / \mathrm{m}^{2}$, the corresponding value of FFMI was $16.7 \mathrm{~kg} / \mathrm{m}^{2}$, and 75 -percentile $=16.6 .{ }^{19}$ Schultz et al., ${ }^{19}$ underscored the advantage of FMI as being a function of age and gender comparing to BMI. ${ }^{19}$ The authors stated that the FFM index has a clinical value "for assessing static and dynamic nutritional status and energy reserves endpoints" compared to BMI and $\%$ BF. ${ }^{19}$

In 1999, The National Health and Nutrition Examination Survey (NHANES) started collecting DXA whole body measurements of $\% \mathrm{BF}$, fat mass $/$ height $^{2}$, lean mass $/$ height $^{2}$, appendicular lean mass/ height ${ }^{2}, \%$ fat trunk $/ \%$ fat legs ratio, trunk $/$ limb fat mass ratio of fat, bone mineral content (BMC) and bone mineral density (BMD) on survey subjects $\geq 8$ years old in three mobile examination centers. ${ }^{17-20}$ Based on data collected in NHANES from 1999 to 2004, Kelly et al., ${ }^{20}$ developed an obesity classification for Fat Mass Index (FMI: fat mass/ height ${ }^{2}$ ) by using prevalence of BMI through established cut-offs and matching thresholds for FMI. ${ }^{20}$ The FMI classification is presented in Table $2 .{ }^{20}$

Peltz et al., ${ }^{21}$ assessed body mass index (BMI), percent body fat $(\% \mathrm{BF})$, and fat mass index (FMI) by anthropometric methods and bioelectrical impedance analyses (BIA) on 538 Mexican Americans (373 women and 165 men) with the objective to investigate the accuracy of FMI as a convenient tool for assessing obesity. ${ }^{21}$ High correlation was observed between $\mathrm{BMI}$ and $\% \mathrm{BF}$ in men $(\mathrm{r}=0.877$; $\mathrm{P}<0.0001)$ and women $(\mathrm{r}=0.966 ; \mathrm{P}<.0001)$; however, $67.2 \%$ of the men and $84.2 \%$ of women were miss-classified as normal weight and overweight by BMI while diagnosed as obese by $\% \mathrm{BF}^{21}$ Correlation between FMI and \%BF was also high in men $(\mathrm{r}=0.975$; $\mathrm{P}<.0001)$ and women $(\mathrm{r}=0.992 ; \mathrm{P}<.0001)$ while misclassification of obesity between FMI and \% BF categories was observed in only $5.4 \%$ of men and $7.8 \%$ of women..$^{21}$ The authors concluded that FMI can accurately assess obesity at least in considered population (Mexican Americans). ${ }^{21}$

\section{Sagittal abdominal diameter (SAD)}

Sagittal Abdominal Diameter (SAD) is assessment of visceral obesity by measuring the distance from the narrowest point between the last rib and the iliac crests to the mid-point of the iliac crests. ${ }^{22-24}$ In the supine position, it is measured to the nearest $0.1 \mathrm{~cm}$ after a normal expiration with bent knees on a firm examination table 
and without clothes at the level of iliac crest (L4-5). It has been shown that SAD correlates with insulin resistance and hyperproinsulinemia (i.e. cardiovascular risk factors) in obese men better than other anthropometric measures (BMI, waist girth, and Waistto-Hip ratio). ${ }^{25}$

A cohort study was conducted by Iribarren et al., ${ }^{22}$ to estimate if visceral obesity measured by SAD predicts coronary heart disease (CHD) above and beyond overall fatness. 101,765 adult members of Kaiser Permanente of Northern California who underwent multiple health checkups between 1965 and 1970, participated in the study. ${ }^{22}$ The results demonstrated that the upper quartile of standing SAD (relative to the lowest quartile) was associated with the increased hazard of CHD in men as 1.42-fold (95\% confidence interval: $1.30,1.55)$, and in women as 1.44 -fold (95\% confidence interval: 1.30,1.59), after adjustment for age, race, body mass index (BMI), educational level, smoking, alcohol consumption, and hormone replacement therapy (in women). ${ }^{22}$ The authors recommended the consideration of joint indices BMI/SAD as better assessment risk of CHD compared with use of BMI alone because SAD was a strong predictor of CHD independently of BMI. ${ }^{22}$

Whitmer et al., ${ }^{26}$ conducted a study to evaluate the association between midlife central obesity and risk of dementia three decades later. $^{26}$ A longitudinal study included 6,583 members of Kaiser Permanente of Northern California who had their sagittal abdominal diameter (SAD) measured in 1964 to $1973 .{ }^{26}$ A total of 1,049 participants $(15.9 \%)$ were diagnosed with dementia 36years later. ${ }^{26}$ The SAD was measured as distance between the back surface and the top of the abdomen at the level of the iliac crest after gentle expiration with the patient in a standing position using an anthropometer; and high SAD was categorized as $\geq 25 \mathrm{~cm} .{ }^{26}$ Participants with the highest quintile of SAD (vs the lowest) had three-fold increased risk of dementia (hazard ratio $=2.72 ; 95 \% \mathrm{CI}$ : $2.33,3.33$ ), and almost two-fold after adding body mass index (BMI) to the model (hazard ratio=1.92; 95\% CI: $1.58,2.35$ ). ${ }^{26}$ The authors concluded that visceral obesity increases risk of dementia independent of diabetes and cardiovascular co-morbidities among mid-aged population and further research is needed to understand the underlying mechanism. ${ }^{26}$

\section{Body volume index (BVI)}

The Body Volume Index (BVI) is a new anthropometric measure of overweight and obesity where 3-dimensional (3D) body scanner with the help of appropriate software performs the assessments of individual's body shape by measuring the total body volume, and eight body segment volumes including the abdomen (central obesity). ${ }^{27-29}$ Basically, the new index automatically measures BMI, waist circumference, and waist-hip ratio in addition to highly sophisticated 3D volumetric and body composition analysis which can differentiate people by body shape and weight distribution with the same BMI level e.g. differentiate muscular/athletic people from those with extra weight around the abdomen. ${ }^{27-29}$

The Body Benchmark Study was a collaborative project conducted by the US and European colleagues that examined BVI through multiple clinical trials. ${ }^{29}$ The results were presented in October 2010, and that time point was considered a formal launch of new anthropometric index. ${ }^{29}$ Currently, BVI is under evaluation by government agencies in the $\mathrm{UK}$ as a possible long-term replacement for BMI; nevertheless, the research still continues and the further studies to assess cut-off values to define overweight/ obesity using BVI and the correlation between BVI and obesityrelated health outcomes are needed..$^{29,30}$

\section{Body adiposity index (BAI)}

Body adiposity index (BAI) was defined by Bergmen et al., ${ }^{31}$ as $\mathrm{BAI}=\left((\right.$ hip circumference $\left.\left.) /\left((\text { height })^{1.5}\right)-18\right)\right)$ with the idea that it can be used to reflect percent body fat (\%BF) for adult men and women of different ethnicities. ${ }^{32}$ The population study "BetaGene" with 1,733 Mexican American participants focused on the development and validation of this new index of body adiposity. ${ }^{32}$ The percent body fat $(\% \mathrm{BF})$ was measured by the dual-energy X-ray absorptiometry (DXA) as a "gold standard" for validation..$^{32}$ The authors choose hip circumference and height as the two components of the BAI formula because of their strong correlation with\%BF (correlation coefficient $\mathrm{r}=0.602$ and $\mathrm{r}=-0.524$, respectively). ${ }^{32}$ After developing formula on "BetaGene" data, the "Triglyceride and Cardiovascular Risk in African-Americans (TARA)" study of African Americans was used to validate the BAI measure. ${ }^{32}$ The results demonstrated strong correlation between DXA-derived $\% \mathrm{BF}$ and the BAI $(\mathrm{r}=0.85) .{ }^{32}$ Bergman et al., ${ }^{31}$ concluded that BAI might be useful in settings where accurate assessment of body weight is problematic, and BAI measures percent of adiposity directly from the hip circumference and height (without weight) for adult men or women. ${ }^{32,33}$

Freedman et al., ${ }^{34}$ had an objective to evaluate if the prediction of $\%$ BFDXA by BAI is more accurate than that achieved by other anthropometric measures: BMI, hip circumference, or waist circumference. ${ }^{33}$ The sample of 1151 participants at the Body Composition Unit of the New York Obesity Nutrition Research Center between 1993 and 2003 was used with \%BF assessed by dual-energy x-ray absorptiometry (\%BFDXA). ${ }^{33}$ The results demonstrated that BAI overestimated \% BFDXA among men(3.9\%) and underestimated among women $(2.5 \%)$ with the magnitudes that varied with the level of body fatness. ${ }^{33}$ The authors concluded that BAI was not more accurate than BMI, waist circumference, or hip circumference. $^{33}$

Lopez et al., ${ }^{33}$ conducted a study with a goal to compare BAI and BMI measurements in a Caucasian population from a European Mediterranean area and particularly to assess the BAI by gender. ${ }^{34}$ 1,726 women and 1,474 men (mean age $=39.2$ years, $\mathrm{SD}=0.8$ ) from Mallorca (Spain) participated in the study. ${ }^{34}$ Tetra-polar Bioelectrical Impedance Analysis (BIA) system was used for assess \% BF; and the body adiposity index (BAI) was calculated using the equation suggested by Bergman et al. ${ }^{32,34}$ The results demonstrated a good correlation of BAI and BMI $(\mathrm{r}=0.64, \mathrm{p}<.001)$, and a strong correlation between BAI and the \%BF $(r=0.74, p<.001)$, which was even stronger than the one between $\mathrm{BMI}$ and $\% \mathrm{BF}(\mathrm{r}=0.54$, $\mathrm{p}<.001) .^{34}$ The authors concluded that the BAI is a good tool to measure adiposity; however, BAI does not seems overcome the limitations of BMI. ${ }^{34}$

A cross-sectional study was conducted in 29.214 men and 21.040 women (aged 20-68years) who were Spanish Caucasian workers. The aim was to evaluate the correlations between Body Adiposity Index (BAI), BMI, waist circumference (WC), waist-to-hip ratio (WHR), and waist-to-height ratio (WtHR) with cardiovascular and metabolic risk factors. ${ }^{35}$ The results demonstrated that BAI was less, and WtHR the best correlated with cardiovascular risk factors and metabolic risk factors than other adiposity indexes (BMI, WC and WtHR). ${ }^{35}$ The authors concluded that WtHR and/or WC are better versus $\mathrm{BAI}$ and $\mathrm{BMI}$ to estimate metabolic and cardiovascular risk 
in both clinical practice and research. ${ }^{35}$ Waist circumference (WC), waist-to-hip (WHR), and waist-to-height (WtHR) ratios became the most acceptable alternatives for measuring central and visceral adiposity. ${ }^{8,9}$

\section{Waist circumference, waist-to-hip and waist- to-height ratio}

The NIH Clinical Guidelines on the Identification, Evaluation, and Treatment of Overweight and Obesity in Adults (September 1998) recommended to use BMI to assess patient's status of overweight and obesity when the goal is to estimate relative risk to disease (use normal weight as a reference); to use body Weight (W) alone if the goal is to monitor weight loss and to determine efficacy of treatments; and to use Weight Circumference (WC) to access abdominal fat content. ${ }^{36}$ In the United States the following WC cut offs are commonly used as a risk factor for obesity-related diseases: $>35$ inches (or $>88 \mathrm{~cm}$ ) for women, and $>40$ inches (or $>102 \mathrm{~cm}$ ) for men. ${ }^{4,8}$ Yet, there are differences in risk among ethnic groups that became an obstacle for development a global grading system for WC. ${ }^{4,8}$ Multiple studies with a goal to estimate the efficacy of therapies based on the changes in WC and BMI assessments faced methodological problems. ${ }^{37} \mathrm{BMI}$ is a measure of total adiposity, WC and WHR are assessments of central adiposity and to find interrelations of these three measures of obesity was impossible. Cardiovascular Health study on 5200 men and women aged 65 and older demonstrated that BMI was a negative predictor of mortality (mortality risk decreased $21 \%$ for every standard deviation increase in BMI after controlling for $\mathrm{WC}$ ), whereas $\mathrm{WC}$ was a positive one (mortality risk increased $13 \%$ for every standard deviation increase in WC after controlling for BMI). ${ }^{38}$ The difficulty of this issue was later explained by Walls et al., ${ }^{38}$ demonstrated that percent change in WC and BMI cannot be directly compared because of the nature of their relationships; or it must account for their association described by the regression equation. ${ }^{38}$ In summary, BMI $\left(\mathrm{kg} / \mathrm{m}^{2}\right)$ and $\mathrm{WC}$ $(\mathrm{cm})$ should be viewed as complimentary measurements. BMI $(\mathrm{kg} /$ $\mathrm{m}^{2}$ ) is the most useful measure of overweight and obesity status to identify individuals at increased risk from obesity-related diseases. Waist circumference WC $(\mathrm{cm})$ is the best practical measure of abdominal fatness, and to identify individuals at increased risk of obesity-related diseases due to abdominal fat distribution. ${ }^{36}$ In addition, WC was the most practical anthropometric measurement for assessing a patient's abdominal fat before and during weight loss treatment. ${ }^{36}$ The NIH Clinical Guidelines on the Identification, Evaluation, and Treatment of Overweight and Obesity in Adults summarized this fact in the Table ES- $4^{36}$ that was further adopted by the WHO Expert Consultation on Waist Circumference and Waist-Hip Ratio. ${ }^{37}$ The table from guidance is presented in Table $3 .{ }^{36}$

Table 3 Classification of overweight and obesity by BMI, waist circumference and associated disease risk (type 2 diabetes, hypertension and cardiovascular diseases)

\begin{tabular}{lllll}
\hline Status & BMI $\left(\mathbf{k g} / \mathbf{m}^{2}\right)$ & Obesity class & Men $\leq 1 \mathbf{0 2} \mathbf{c m}(\leq \mathbf{4 0}$ in $)$ Women $\leq \mathbf{8 8 c m ~}(\leq 35 \mathrm{in})$ & $\mathbf{> 1 0 2} \mathbf{c m}(>\mathbf{4 0})>\mathbf{8 8 c m}(>\mathbf{3 5} \mathrm{in})$ \\
\hline Underweight & $<18.5$ & - & - \\
Normal\# & $18.5-14.9$ & - & - \\
Overweight & $25.0-29.9$ & & Increased & High \\
Obesity & $30.0-34.9$ & $\mathrm{I}$ & High & Very High \\
& $35.0-39.9$ & $\mathrm{II}$ & Very High & Very High \\
Extreme Obesity & $\geq 40$ & $\mathrm{III}$ & Extremely High & Extremely High
\end{tabular}

\# Note, that increase waist circumference can also be a marker for increased risk even in persons of normal weight persons of normal weight persons of normal weight

\section{Conclusion}

This paper is a brief review on development of multiple indices measuring body weight. The history and purpose of each index, as well as their weaknesses and advantages is summarized. This review will help researchers to choose the best body weight measurements to address objectives. On the other hand, this paper may motivate researchers to develop and validate a new index because each measurement has limitations and work on the perfect one is still ongoing.

\section{Acknowledgements}

None.

\section{Conflict of interest}

The author declares no conflict of interest.

\section{References}

1. Quetelet LA. A Treatise On Man And The Development Of His Faculties. Obes Res. 1994;2(1):72-85.
2. Livi R. L'indice ponderale o rapport tra la statura e il peso. Atti Sot Romana Antrop. 1897;5:125-153.

3. Florey CV. The use and interpretation of ponderal index and other weight-height ratios in epidemiological studies. $J$ Chronic Dis. 1970;23(2):93-103.

4. Rohrer Fritz. Der Index der Körperfülle als Maß des Ernährungszustandes [The index of corpulence as measure of nutritional state]. Münchener medizinische Wochenschrift (in German). 1921;68:580-582.

5. Billewicz WE, Kemsley WF, Thomson AM. Indices of adiposity. $B r J$ Prev Soc Med. 1962;16:183-188.

6. Khosla $\mathrm{T}$, Lowe CR. Indices of obesity derived from body weight and height. Brit J Prev Sot Med. 1967;21(3):122-128.

7. Keys A, Fidanza F, Karvonen MJ, et al. Indices of relative weight and adiposity. J Chronic Dis. 1972;25(6):329-343.

8. Robert J Kuczmarski, Katherine M Flegal. Criteria for definition of overweight in transition: background and recommendations for the United States. Am J Clin Nutr. 2000;72(5):1074-1081.

9. R J Jarrett. Is there an ideal body weight? British Medical Journal. 1986;293:493-495. 
10. Cora E Lewis, Kathleen M Mc Tigue, Lora E Burke, et al. Mortality, Health Outcomes, and Body Mass Index in the Overweight Range:a Science Advisory From the American Heart Association. Circulation. 2009;119(25):3263-3271.

11. Cuilin Zhang, Kathryn M Rexrode, Rob M van Dam, et al. Abdominal Obesity and the Risk of All-Cause, Cardiovascular, and Cancer Mortality. Sixteen Years of Follow-Up in US Women. 2008;117:1658-1667.

12. Frankenfield DC, Rowe WA, Cooney RN, et al. Limits of body mass index to detect obesity and predict body composition. Nutrition. 2001;17(1):26-30.

13. Crystal Man Ying Leea, Rachel R Huxleya, Rachel P Wildman, et al. Indices of abdominal obesity are better discriminators of cardiovascular risk factors than BMI:a meta- analysis. J Clin Epidemiol. 2008;61(7):646-653.

14. Snijder MB, Van Dam RM, Visser M, et al. What aspects of body fat are particularly hazardous and how do we measure them? Int J Epidemiol. 2006;35(1):83-92.

15. Paul Deurenberg, Jan A Weststrate, Jaap C Seidell. Body mass index as a measure of body fatness: age- and sexspecific prediction formulas. $B r J$ Nutr. 1991;65(2):105-114.

16. Siri SE. Body composition from fluid spaces and density: analysis of methods. In: Brozek J, Henschel A, editors. Techniques for measuring body composition. USA: National Academy of Sciences, National Research Council; 1961. p. 223-234.

17. Romero Corral A, Somers VK, Sierra-Johnson J, et al. Accuracy of body mass index in diagnosing obesity in the adult general population. International Journal of Obesity. 2008;32(6):959-966.

18. VanItallie TB, Yang MU, Heymsfield SB, et al. Height- normalized indices of the body's fat-free mass and fat mass: Potentially useful indicators of nutritional status. Am J Clin Nutr. 1990;52(6):953-959.

19. Schutz Y, Kyle UUG, Pichard C. Fat-free mass index and fat mass index percentiles in Caucasians aged 18-98y. International Journal of Obesity. 2002;26(7):953-960.

20. Thomas L Kelly, Kevin E Wilson, Steven B Heymsfield. Dual Energy X-Ray Absorptiometry Body Composition Reference Values from NHANES. PLoS One. 2009;4(9):e7038.

21. Gerson Peltz, Maria Teresa Aguirre, Maureen Sanderson, et al. The Role Of Fat Mass Index In Determining Obesity. Am J Hum Biol. 2010;22(5):639-647.

22. Iribarren C, Darbinian JA, Lo JC, et al. Value of the Sagittal Abdominal Diameter in Coronary Heart Disease Risk Assessment:Cohort Study in a Large, Multiethnic Population. Am J Epidemiol. 2006;164(12):11501159.

23. Petersson Helena, Daryani Achraf, Risérus Ulf. Sagittal abdominal diameter as a marker of inflammation and insulin resistance among immigrant women from the Middle East and native Swedish women: a cross-sectional study. Cardiovascular Diabetology. 2007;6:10.

24. De Almeida Paula HA, de Cássia Lanes Ribeiro R, de Lima Rosado LEFP, et al. Relationship between waist circumference and supine abdominal height measured at different anatomical sites and cardiometabolic risk factors in older women. Journal of Human Nutrition and Dietetics. 2012;25(6):563-568.
25. Risérus U, Arnlöv J, Brismar K, et al. Sagittal Abdominal Diameter Is a Strong Anthropometric Marker of Insulin Resistance and Hyperproinsulinemia in Obese Men. Diabetes Care. 2004;27(8):20412046.

26. Whitmer RA, Gustafson DR, Barrett-Connor E, et al. Central obesity and increased risk of dementia more than three decades later. Neurology. 2008;71(14):1057-1064.

27. Tahrani Abd, Kristien Boelaert, Richard Barnes, et al. Body volume index:time to replace body mass index? Endocrine Abstracts. 2008; $15: 104$.

28. The National Horizon Scanning Centre. Body Volume Index 3D Scanner for obesity. UK: University of Birmingham; 2010.

29. Jack Wang, Dympna Gallagher, John C Thornton, et al. Validation of a 3-dimensional photonic scanner for the measurement of body volumes, dimensions, and percentage body fat. Am J Clin Nutr. 2006;83(4):809816.

30. Korenfeld Y, Ngwa T, Friedman L. Validation of a Novel $3 D$ Body Scanner for Obesity Anthropometric Measurements. AHA $26^{\text {th }}$ Princeton Conference on Cerebro-vascular Disease, Houston, Texas, USA; 2009.

31. Richard N Bergman, Darko Stefanovski, Thomas A Buchanan, et al. A Better Index of Body Adiposity. Obesity (Silver Spring). 2011;19(5):1083-1089.

32. Bennasar-Veny M, Lopez-Gonzalez AA, Tauler P, et al. Body Adiposity Index and Cardiovascular Health Risk Factors in Caucasians: A Comparison with the Body Mass Index and Others. PLoS ONE. 2013;8(5):e63999.

33. López AA, Cespedes ML, Vicente T, et al. Body Adiposity Index Utilization in a Spanish Mediterranean Population: Comparison with the Body Mass Index. PLoS One. 2012;7(4):e35281.

34. Freedman DS, Thornton J, Pi-Sunyer FX, et al. The body adiposity index (hip circumference $\div$ height $(1.5)$ ) is not a more accurate measure of adiposity than is BMI, waist circumference, or hip circumference. Obesity (Silver Spring). 2012;20(12):2438-2444.

35. National Institutes of Health. The Practical Guide identification, evaluation, and treatment of overweight and obesity in adults. The evidence report Obes Res. 1998;6:464.

36. World Health Organization. Waist Circumference and Waist-Hip Ratio. Report of a WHO Expert Consultation. Switzerland; 2012. p. 8-11.

37. Janssen I, Katzmarzyk PT, Ross R. Body Mass Index Is Inversely Related to Mortality in Older People After Adjustment for Waist Circumference. $J$ Am Geriatr Soc. 2005;53(12):2112-2118.

38. Walls HL, Peeters A, Mannan H, et al. Methodological problem with comparing increases in different measures of body weight. BMC Res Notes. 2011;4:145. 